Historic, archived document

Do not assume content reflects current scientific knowledge, policies, or practices. 

62.13

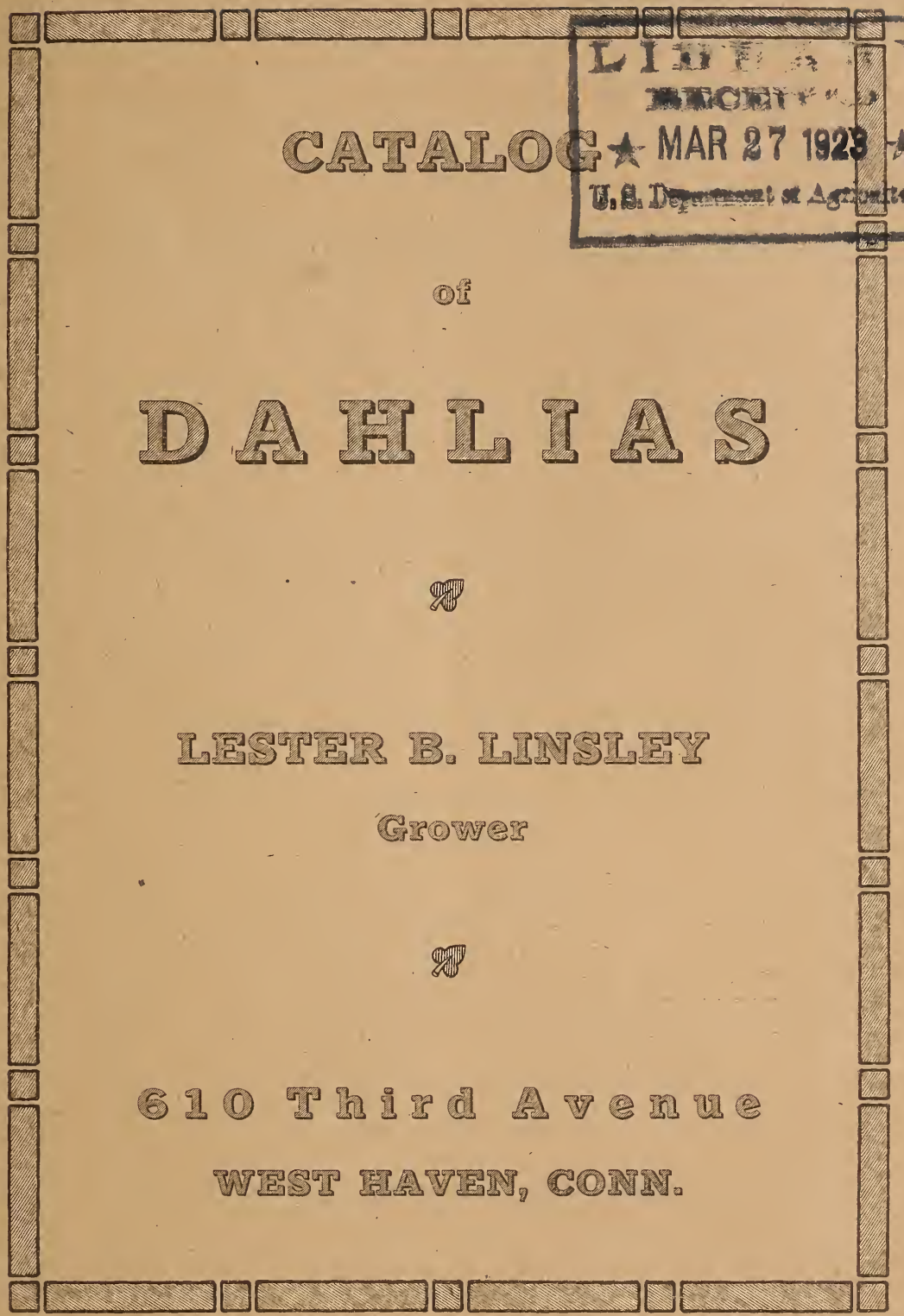




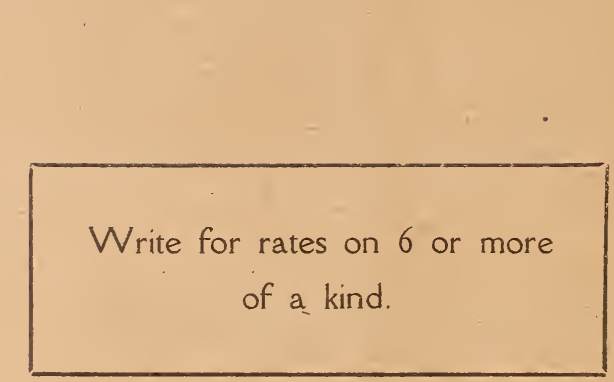




\section{Catalog of \$ablías}

\section{LESTER B. LINSLEY, Grower}

610 THIRD AVENUE

WEST HAVEN, CONN.

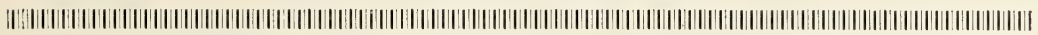

\section{INSTRUCTIONS-INFORMATION}

To those who are unacquainted with the different classes and varieties of Dahlias I would suggest that such leave the selection to me. Send me the amount of money you wish to invest, and in return I will send you those that will surely delight. Also my liberal filling of the order will more than be satisfactory.

ORDER EARLY. As orcers are filled in rotation, ordering early will insure the reservation of varieties that later may be sold out.

SUBSTITUTION. Orders are filled with varieties called for, and unless substitution is asked, I never substitute.

TIME OF SHIPMENT. Unless otherwise ordered, tubers will be shipped af er April 15, by express or insured mail.

Small orders of Dahlia tubers will be sent by mail, larger orders by express.

TERMS. Cash with order, or in advance of shipment. Postage prepaid on all retail orders when payment in full is made, at time of ordering.

I warrant all roots and plants, to be healthy, and true to label, but having no control over them, after delivery, I do not guarantee them to live and thrive, nor will I rep'ace them except any plant should prove untrue to name; but in no case will I be liable for any sum greater than the original purchase price.

Referring to the description in this list, there ought to be made a certain allowance for variation, caused by different soils and climatic conditions. 
REMITTANCES should be made by bank draft, postoffice money order or registered letter.

ERRORS. While my system for handling orders is as near perfect as possible, yet in the rush of business errors are possible to occur, and I wish to be promptly notified of such and will at once make satisfactory. Keep copy of your order for comparison.

NAME AND ADDRESS. Remember to write your NAME, POSTOFFICE, COUNTY and STATE; also give STREET NUMBER or P. O. BOX as plainly as possible.

DAHIIAS BY THE DOZEN, multiply the price by 10 .

In this Catalog I have used the originator's description in most cases.

Write for rates of 6 or more of a kind.

LESTER B LINSLEY.

610 Third Avenue, West Haven. Conn. 


\section{敖}

\section{Dablía}

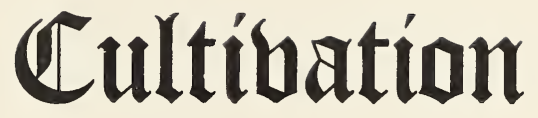

LOCATION. The Dahlia requires first a sunny, airy location, and yet sheltered from the heavy summer winds. If dahlias are planted in the shade the result will be that they will grow to a great height nad produce but a very few flowers of a weak nature.

SOIL. Dahlias will grow in any or all kinds of soil, if properly fertilized, with very good results. Most failures are due to neglect in having the soil thoroughly worked before planting by spading deep and making as light as possible.

FERTILIZING. Give your garden a good coat of stable or cow dressing and spade well into the soil in the fall where you intend to plant them in the spring. Then when planting time comes you can use any good commercial fertilizer, about a handful to the hill, well covered over before setting the bulb.

TIME TO PLANT. Dahlias may be planted with good results from May 1 to July 1. In our New England climate May 15 to first of June is perhaps as well as any time. 
DEPTH TO PLANT. Place the tubers diagonally about four inches below the soil. If the ground is cold and very moist it is far better to start them in shallow boxes covering them with moss or earth; keep moderately wet and place them in a warm place or hotbed and they will start quickly. After they are up, say two inches, transplant them to your field three feet apart and the rows should not be nearer than three feet.

FEEDING. After the plants are 8 to 13 inches high give them a good mulching of rotten cow dressing; some ground bone worked around the hill will be all righ: to use. As soon as the bulbs appear, water them with liquid made from sheep dressing or cow dressing. This ought to produce some fine blooms with good stems.

HOEING AND CULTIVATING. From the time the plants are out of the ground until they begin to bud and bloom the ground should be well hoed and kepi free from weeds and at"all times ground should be raked orer especially around plants to conserve moisture.

WATERING. This is the most important and yet difficult question to solve. There is no rule as to how and when to water, only one's judgment. Watering too much is as bad as not enough. But bear in mind if artificial watering is done it must be kept up from rain to rain, and when watering be sure to water enough to reach the roots. The best time to water is at sunset.

INSECTS AND WORMS. One of our first pests is the cut worm, which comes in-time to cut the tender shoots. There is a remedy on the market in powder form called Vaporite, which is claimed will destroy them. Next comes the borer, which is noticed by the wilting of the plants. The best way to kill him is to app:y a weak so:ution of arsenate of lead injected into the stock at the top, where the stem is hollow. We have white and green aphis which can be kept in check by any of the nicotine solutions, sprayed over the plants. The cinch bug, our worst enemy, can be kept in check by the use of Pyrol sprayed once or twice a wcek.

LIFTING AND STORING. After frost has taken and blackened the plants, cut them down. Select a p'easant day for digging, between the hours of 9 and $t$. Dry and shake cff what dirt corcs easily, and pack them in a dry, cool cellar, which can be kept at 40 to 45 degrees. 


\section{艧以

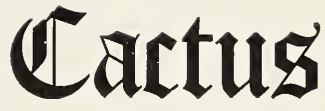 \\ 两ahlias}

ALABASTER. (Stredwick). A flower of purest white, and a variety that has come to stay. The blooms are of large size, and just sufficiently incurved in form to show to advantage when exhibited. The plants are s.urdy and dwarf, and carry the flowers boldly on stout erect stems. We predict that this will supersede all other white Cactus, it being one of the most genuine varieties we have ever raised. Height 4-ft. Price

BRITISH LION. (Stredwick). Rarely have we had such truiy monster flowers as those of "British Lion." The blooms being composed of a great number of long twisted and curling petals, not particularly narrow, the flowers presenting a massive appearance. The color is peculiar, yellowish for the most part, but burnished with red, almost, it might be termed, tawny in color. Plants strong and produce huge flowers without any unduly rich culture. Unique and wonderful. Height 5-ft. Price

CAPT. BAIRNSFATHER. (Stredwick). It is quite usual for people to refer to certain Cactus Dahlias as "Those shaggy ones" and this var.ety is one of the most pronounced of this class, the florets being narrow, incurved and interlaced. Color red overlaying orange and yellow with yellow more decided at center. Plants almost too free, and stems of average length and wiry. Height 5-ft. Price

GOLDEN RAIN. (Stredwick). Clear yellow, deeper at center, to primrose at tips. From very incurved, center good, and flowers have a clean neat appearance, reminding one of the var:ety "Miss Stredwick," and although dwarfer the foliage and habit of plants favor that variety. This is a typical exhibition Cactus, especially for showing in bunches. He:ght 3-ft., 6-in. Price

GUARDIAN. (Stredwick). A giant flower, carried on an upright stem as stiff as cane. The color too is as imposing as could well be in conjunct:on with the lold type of flower. A glowing crimson scarlet throughout. Quite the most striking novelty we have introduced for some years, judged from a decorative standpoint. All should grow this. One of the best. Height 5-ft. Price 


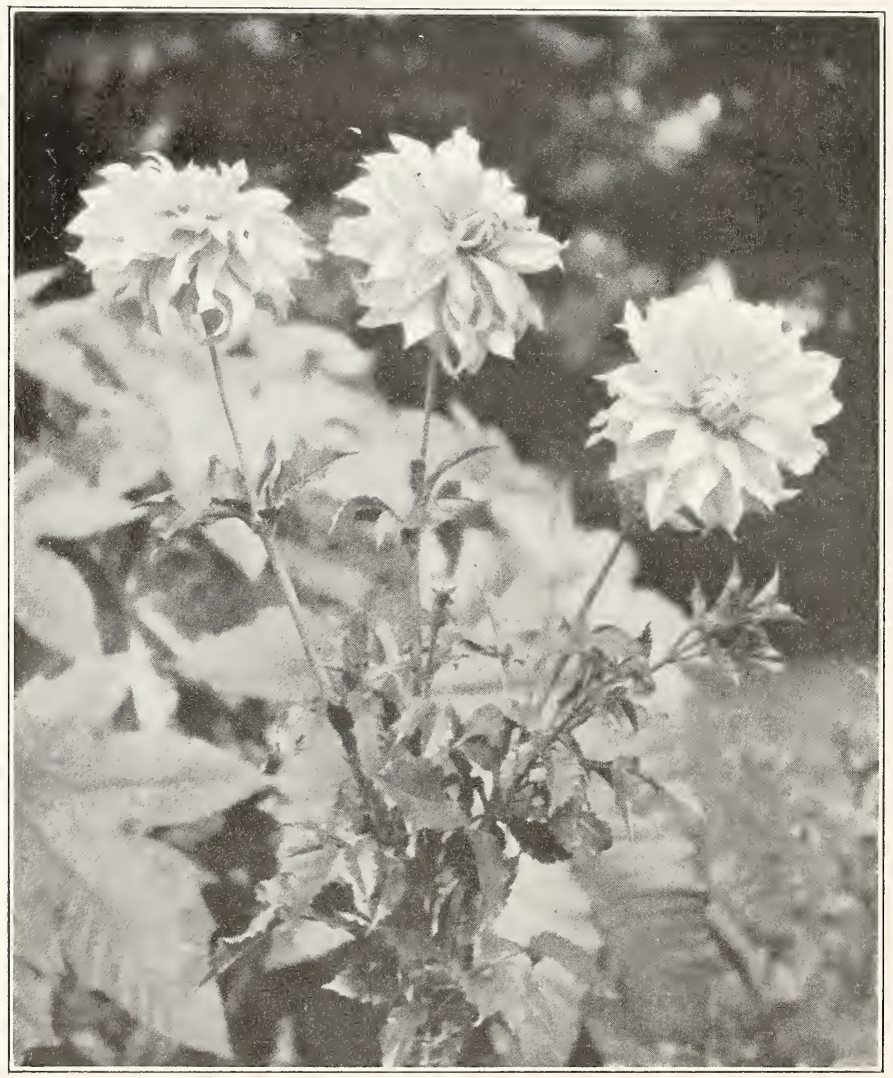

RUTH LINSLEY. Light yellow flowers right on the top of stems like Insulinde but a much better stem and flower with extra some good habits and follage. Price $\$ 8.00$ 
LIEUT. ROBINSON, V. C. (Stredwick). One of the indispensable to the up-to-date exhibitor. The flowers are of largest size, and composed of a mass of narrow florets, incurving, twisting and interlacing so as to finally almost cover the center which never shows pollen right to the last petal. The plants are of wiry growth, and fairly good habit but the flower stems are not upright. Color clear ruby, with amaranth at tips, and on older florets. Height 4-ft., 6-in. Price.

60 cents

MRS. MARGARET STREDWICK. Far and away the finest Dahlia we have ever raised, and one combining so many good points, that we are in no danger of exaggerating its merits. The coloring is a combination of tints of pink, sofiening and deepening at tips and base. The form as perfect as poss:ble, and what is the more remarkable the plants have. a grand habit, with strong, stout, upright flower stems. In fact as grown with us, this is the Cactus Dahlia we have been working for as raisers for many years. He ght 4 -ft, 6 -in. Price

MRS. HERBERT BLACKMAN. (Stredwick). No longer can it be said that Cactus Dahlias are weak stemmed. This is another variety with a splendid stem, long, stiff and upright, carrying flowers of good size and evenly incurved shape. Color, pretty rosy pink on older florets, then lighter to blush and finally white at center. A Cactus useful for any purpose, and in many respects a decided advance. Height 5 -ft. Price

MRS. JOHN FOWLER. (West.) A beautiful maroon crimson. The florets are long, narrow, and incurving, forming a bloom of good quality and form. Quite distinct, very constant. Height 3-ft. Price 60 cents

PLANET. (Stredwick). A fancy Cactus. White at base of florets, changing to rosy pink, the whole spotted and striped with scarlet. Flowers large and of typ.cal neat, incurved exhibition form. Habits of plants, grand dwarf, sturdy, free, and with stiff flower stems. The best fancy for some years. Height 4 -ft. Price

SIR DOUGLAS HAIG. (Stredwick). Our best for 1920. The flowers are of perfect form, the s'ender tubular florets incurving and twisting irregularly, and making ideal exhibition flowers of good size. The plants have an upright style of growth with capital long flower stems. The color too is second to none, being a lovely combination of tints of pink, grading from almost white to deep, then to lighter again. He:ght 5-fi. Price 50 cents 
SAFFRON. (Stredwick). An exhibition Cactus, the flower being of good size and beautifully refined form, the slender florets being very incurved and more or less interlaced as the blooms develop. The plants are strong growers and free but the flower stems, though long, are not erect. Color a uniform medium clear yellow. Height 5-ft. Price

TREASURE. (Stredwick). The most striking feature of this flower is its color, white at base, quickly changing to deep clear rose, the extreme tips being yellow. Growth of plants strong, sturdy and stiff siemmed. Form slightly incurved the blooms favoring the bold type rather than the refined. Height 4-ft., 6-in. Price

\section{Pek Cactus 西ablía}

\section{CACTUS DAHLIA}

ATTRACTION. Large elegant flowers of a clear lilac rose color, long strong stem. Will be an attraction in every Dahlia show. It is an exhibition flower and garden Dahlia of rare merit. Height 5-ft. Price $\$ 1.00$

BIANCA. An exceptionally well formed broad-petalled hybrid cactus of a pleasing soft rosy lilac; very free flowering. Price 75 cents

BULL MOOSE. Hybrid Cactus. Color of outer petals a beautiful shade of pinkish yellow. Petals slim and quite plentiful. Center petals changing to canary yellow. A good flower with long stems. Large size and a fine specimen. Free bloomer. Price

COUNTESS OF LONSDALE (Cactus). No better cactus dahlia grown; free and good stem, color salmon pink. Good all around dahlia. Price 25 cents

CONQUEROR. A great bloomer. The flower stems are stiff as cane.

Color, crimson. Price

ELSIE BONNELL. One of the best cut flowers that we know. Deep, rich velvety crimson, excellent stem and very large flower, early and free. Price 75 cents

F. W. FELLOWES. (New introduction). Undoubtedly the best variety of recent introduction in the cactus type, having fine form and habits. Flowers are extra large on very long stems, and remarkably contant. Color, orange scarlet, with long straight florets. Height 5 -ft. Price .... 75 cents 
MARGUERITE BOUCHON. A beautiful shade of light pink with lighter cen er. The largest pink Cactus Dahlia known. The petals are long and slim, and are produced in unlimited numbers. A most wonderful production in Cactus Dahlias. Price 75 cents

MRS. HUBERT ALLEN. Lovely large Lavender H. C. long stems, free Price

PIERROT: An un que and striking novelty. The color being deep amber, shaded darker and tipped with pure white. The flowers are very large and habit good. Price 75 cents

RHEINISCHER FROHSINN. Carmine with shadings of white and pink at base. A beautiful flower. Price 50 cents

WM. SALTSAM. 1915 seedling, good long stems, well above foliage bloom. Height, 5 to 8 in. Free blooming. Fine shade of red. One of the best. Price

\section{唒pbrii Cactus 五ablia}

ATTRACTION. (Hybrid). Large, full flower, of a clear, lilac-rose; long strong stems, holding the bloom stiff and upright

GEO. WALTERS. One of the largest Dahlias ever introduced; very free flowering, a pleasing shade of salmon-pink shading to yellow at the base Height 6-in. Price

INSULINDE. (Hybrid Cactus). A giant bronzy orange with a salmon tint. Beautifu! au umn shade. Flowers always on upright, long stiff stems Cne of the very best.

JOHN RIDING. Bright scar'et. Large flower with long, slim petals. Price 75 cents

KALIF. A mons er cactus of perfect form. Color is a rich, pure scarlet. The large flowers are borne on long, $s^{t}$ iff stems and are held erect. A most satisfactory variety. Height 5 -ft. 
LADY HELEN. A beautiful hybrid Cactus Dahlia as distinctly new in quality and excellence as in origin; standing erect on long stems with finely formed and curled petals spreading out, making a diameter varying from $7 \mathrm{~T} / 2$ to $8 \mathrm{r} / 2$ inches. It is a striking and beautifully toned pink in the main body coloring, with slight veins of white, almost cream, running through the petals. Prominent cream tips make a decidedly new and altogether forcible addition to the who!e flower. The Dahlia should be seen to be fully appreciated, for words of pen cannot do it justice. A profuse bloomer. Price

MADONNA. A free blooming variety with large white flowers, the petals being curled and pointed in such a manner as to make it very distinctive.

MT. SHASTA. Hybrid Cactus. Very light shell pink with slightly deeper shadings of pink through the petals. A faint tinge of yellow shows toward center. Peials long, slim and rolled at points. An extra fine, full, deep flower and enormous size. This flower when grown to perfection is simply a wonder in size, shape and color. Stands very erect on good, stout stems. Price

MRS. WARNAAR. A mammoth hybrid cactus, often 9 inches in diameter. Creamy white with just a tinge of pink. One of the finest of the new dahlias. Price Each $\$ 1.00$

NIBELUNGENHORT. Similar to Wodan in form. Rose color with a golden suffusion.

OAK LEAF HYBRID. (Show). This has a wonderful foliage thus the name, stems 18 to $20 \mathrm{in}$, large flowers, upright plant, yellow tipped red. Price

RADIN KARTINI. Sa'mon shade with lilac and mauve. Large flower, strong stems. Very free bloomer. Va!uable acquisition.

RUTH GLEADELL (Seal). Beautiful large blossoms of soft yellow shading to pink at the outer edge of the petals. Excellent as to form and stem, and is a wonderful cut flower. Is known as the "California Sunburst Dahlia." 


\section{Sôs}

\section{Aecoratíne Jahlía}

Decorative Dahlias are becoming increasingly popular, especially the larger flowered varieties. They have certainly much to recommend them, being of easy culture, imposing size, and last well when cut.

AIDA. Dark maroon large perfect flowers on rigid upright stems, carried high above the foliage. (Bronze Medal.) Price 50 cents

AQUITANA. The color of this gorgeous, new Cactus Dahlia is a beautiful salmon pink. The flowers are very large and are borne on long stems with scant foliage, making it most desirable for cutting. Price $\$ 2.00$

ALASKA, No. 935. Pure glistening white with quite broad, slightly rolling floret and numerous small curly petals around disc. The flower is borne on long jointed stems and is a very good Dahlia for cut flower purposes. Price

BEN WILSON. Color rich velvety red; each petal having just a tip of yellow; the amount of yellow varying according to conditions. Plants are good growers and bloom profusely.

BEITTRA PRINCE DEC. Lavender, good long stems, heavy dark green fol:age, large fine blooms 6 to 8 in., well above the foliage. Price ........ $\$ 5.00$

CREAM KING. (New introduction.) Among the new varieties tried out during the past season, the Cream King has proved to be ahead of any. The co.or is of soft primrose and cream. Blossoms are monstrous and bloom clear into frost, and are held erect on stems which average $2 \mathrm{ft}$. long. The habit of the plant is excellent in every way. Height 5-fi. Price

C. E. LINSLEY PEONY DEC. Lavender, extra long stems, weil above the foliage, the foliage is very dark green, good large flowers and free. Price

CARMENCITA. A most graceful and beautiful Decorative. The yellow blossom is regularly striped red. 'The plant is a dwarf grower but forms a fine compact bush which is a mass of flowers all season.

CARMEN SYLVIA. Lovely shade of salmon. Flowers medium, perfect form; profuse bloomer. Long stiff stems. Holland creation. 
DAKOTA. F ne large flowers held well above the foliage; extra large; color shade of flame; good for exhibition or garden; fine foliage; rank grower. Price

DR. H. TEVIS. A decorative of enormous size. Flowers measure 9 to 11 in. in diameter, held erect on long stiff stems, a pretty shade of salmon rose, suffused with old gold.

DREAM. A new Holland reation. Flowers of supreme beauty; a lovely combination of peta's. Price

50 cents

ETHEL FLINT. Long growing plant, blending of salmon pink, free good stems. Price 35 cents

FRAU. G. SCHIFF. A beautiful blending of apricot, orange and yellow with reverse of petals coral red. Early and continuous bloomer. Plants are of good habit. Blooms heid well above the foliage.

H. C. LINSLEY RED DEC. Very full flower, split petals, good stems and follage, blooms right on top of stems well above the foliage. Price $\$ 250$

HORTULANTS FIET. Most delicate shade of pink, tip of each petal barely tipped with gold. The entire flower has a suffusion of delicate ints of red and yellow, which gives a glow, yet softness of color diffcult to describe. Large flowers, often measure 8 inches. Price. $\$ 1.00$

JANE SELBY. Exceptionally large flower of a delicate mauve pink, great substance and beautiful form on strong stems high above the foliag: ; a prize winner. Price

JANET This is a large cherry red Decorative of wonderful keeping qualities. Experts who saw it at the New York show on the last day ordered it freely. If you want a "kceper" with good stems, color and erect habit, you need Janet. Scored 90 points at S:orrs, Conn., trial grounds. Price 
LE GRAND MANITOU. White ground, heavily striped and blotched with violet red, fine and large with high full center. Price

L. E. LINSLEY DEC. Orange shaded red at base of center, long hard black s:ems, flowers well above the foliage, blooms 6 to 8 in. Price.... $\$ 8.00$

MARY BUTTON. Dec. 1921 seeding, sell 1924. Lavender showing faint tint of pink, extra large blooms, good stems and strong growing with thick heavy leaves, good for exhibition. Price

MARION LINSLEY DEC. Tall growing plant, extra long stems, blooms well above the foliage, looking straight at you, yellow tipped, pink with go!den shean on the pink. Price

MAJORIE FIELD. A beautiful large pink Decorative with shadings of rose color. A Dahlia that is a pleasure to possess

MRS. CARL SALBACH. One of the most popular of California Decoratives. A lavender pink in color. The immense blooms are held erect on long straight stems. Good keeping qualities. A heavy prize winner.

MRS. L. B. LINSLEY. White Decorative. Extra free blooming, stems 15 to 20 inches, dwarf growing. You do not have to cut the top of this Dahlia to have it branch.

PORTHCS. (Marion). Very vigorous grower, splendid dark green foliage, good stems, well above the foliage. Large size and rich dark red.

PURITY. One of the finest bloomers, large flowers, sturdy plants, a grand cut flower. White 
ROYAL PURPLE. Solid rich purple. Solid color throughout. Quite large and desirable. Price 35 cents

ROSY MORN DEC. Color of old rose, tall growing plant, medium free extra long stems, large flowers. Price

SAMONA. Extra nice pink. Decorative; very free and robust stem, 12 to 20 inches; flower 4 to 6 inches 50 cents

SOUVENIR DOUZON. An immense flower with broad, flat petals and full to the center. This one is undoubtedly the largest red in the decorative section. Price

25 cents

SULPHUR KING. Th's is considered 'tc be the best yellow cut flower in the market today. Blooms, five to six inches, always full to the center, on stems two feet long, a wonderful good keeper. Awarded a Certificate of Merit 75 cents

THE TANGO. Pure tango color; medium flowers on good stems. Price.... 50 cents

TERRA COTTA. (New.) Very fine flower of a beautiful terra-cotta shade; very large and distinct 50 cents

THE PRIDE CF CALIFORNIA. A novelty. Called the American Beauty Dahlia. This Gold and Silver Medal dahlia is crimson red, with dark fu'l ce ter. Huge flowers on long straight stems. Excellent for exhibition, garden and a cut-flower with fine keeping qualities $\$ 1.00$

THE MILLIONAIRE. A monster Dahlia. (See illustration on page 2.) Delicate lavender-pink with a faint pirk cast overshading it. The full-. ness of the flower and the finely shaped petals make the formation perfect. The immedate center is almost pure white. Although the flower is unusually heavy, the strong stem keeps it well erect

VIRGINIA LINSLEY DEC. Sell 1924. Light lavender large flowers, 7 to 8 in. and over the Indges, awarded me first prize, 1921 seeding at the New Haven County Dahlia Exhibition. Tall growing plant, free blooming stems from 2 to $4 \mathrm{ft}$. Price

VIRGINIA DARE. In this new December Seedling I have the best florist's Dahlia to my knowledge, in fact the first Blooming Dahlia that I ever saw from 4 to 6 inches in size, stems from 12 to 20 inches long, free branching labit, flowers held upright and very rigid. Color white with a tinge of lavender, pink center.

W. E. LINSLEY DEC. Light yellow, good habits and stems and foliage, large flowers. Price 


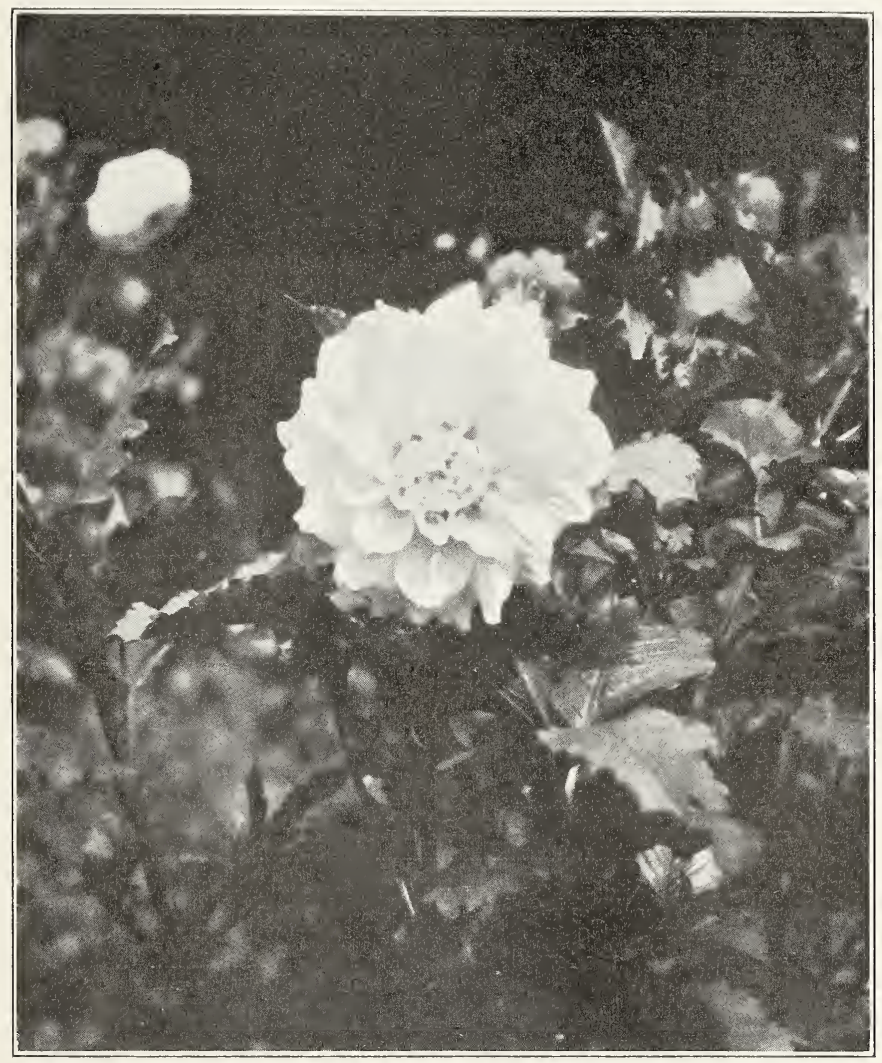

ET TA BUTTON. Dec. 1921 seeding, sell 1924. White with very faint tint of yellow in center when fully open, when the flower commences to open faint tint of lavender on back of petals. Blooms 8 to $10 \mathrm{in.}$ and never shows center. Extra long stems, heavy dirk green foliage. Extra good for exhibition and cut flowers. Price $\$ 25.09$ 
IVEST HAIEN DEC. Sell 1924. Splendid dark red with stems $3 \mathrm{ft}$. long. Blooms 6 to 8 in., free and a vigorous grower, very dark green foliage. Price

IVONDER PINK PEONY DEC. Splendid color, sometimes Dec. sometimes Peony, extra large blooms weli above the dark green foliage. with good stems.

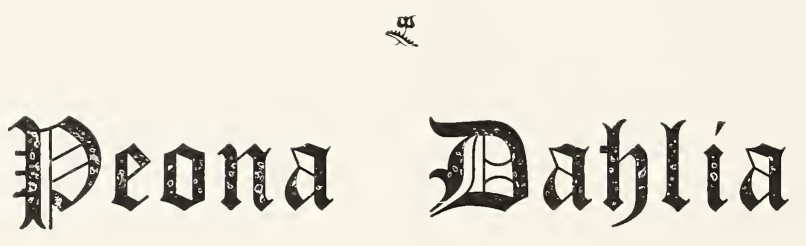

ELSA. Fluffy white flowers, yellow center, large size and showing high above the foliage; unsurpassed as a cut flower. The best white Paeonia Dahlia, its sterling qualities are appreciated more every year; demand always larger than the supply. Price

GEISHA. A superb combination of brilliant scarlet and gold. Most attractive of this type in existence. Brilliant shades of scarlet-yellow and gold with a lovely ring of golden yellow at the center. Petals twisted and curled. Very fine bloomer. The sensation of the garden $\$ 1.00$

G. H. CARR. (New introduction.) Undoubtedly one of the largest Dahlias grown; a giant in every meaning of the word. Color is a deep clear purple with velvety reflex. Very sturdy. Flowers are produced on long stiff stems, showing the full face of the flower. $4 \mathrm{ft}$. Price

GEO. H. MASTICK. Large flowers of many wavy petals; full to the center on strong stems. Color is b!ackish maroon with currant tips to outer row of peta!s. Very free bloomer

HELIO. The color is a deep br:ght canary yellow. It is of the peony type and the stems are very long and wiry and hold the flowers correctly. The flowers are of the very largest size and enormously free-blooming. The growth is strong and healthy. It is perfect in every respectone of the finest productions ever put out. Price

HAMPTON COURT. (Peony.) One of the best yet introduced. A bold flower of good form; of a brilliant mauve pink. Price 35 cents

JEAN ANDERSON, No. 1118. Salmon buff slightly clouded with deep yellow. The sty'e of this flower is very unique, with its small twisting petals around the center and the curly features of the large ones. One of the entirely new shades. Price 
LILLIAN LINSLEY. The best light pink Dahlia to date, extra long stems, free branching and covered with flowers all season, won first prize in American Dahlia Society, 1920. Peony class. 25 blooms.

35 cents

MEYERBEER. (New introduction.) This is reckoned to be the largest Peony-flowered Dahlia in commerce. The unique coloring of purple lined crimson is most distinct and striking. The monstrous blooms are held erect on long stems. Price

75 cents

MABEL LINSLEY. Picric yellow, tall, upright grown, with fine cut foliage, large flowers on good stems, received Certificate of Merit at the trial grounds of the American Dahlia Sxiety at Storrs College, Storrs, Conn. Price

RUTH NICHOLS. An immense flower borne on long stem. Rich dazzling red. A leader among the reds by reason of its great size and freedom of bloom. S rong and vigorous. Price 50 cents

STENDARD DE LYON. Large and massive yet graceful and free on long strong stems. Color, reddish vio?.et overlaid Tyron rose 50 cents

TANGO. Large peony type of wonderful coloring consisting of bronze and salmon. Fine stem and a prolific bloomer. Splendid as a cut flower. A California production. Price 50 cents

THOS. GALVIN. Body old gold, slightly shaded pink. A deep heavy fluffy flower. Peta!s broad and long and twisting. The reverse side of petals clouded pink and showing from the front where the petals roll up. A wonderfully fine, mammoth, new Dahlia. Price $\$ 1.00$

VAN DYKE. (Peony.) Clear salmon overlaid, rose pink, heliotrope shaded, one of the best bloomers. Price 35 cents 


\section{Shom}

\section{$\mathbb{Z} \mathfrak{A} \mathfrak{a} \mathfrak{h l i a}$}

A. D. LAVONI. Show. Delicate pink. Well formed flowers with long stems. Very desirable for cutting. This is an old standard Dahlia which every Dahlia grower has retained from its introduction, on account of its exquisitely beautiful color and perfectly round, ballshaped flower. One of the freest blooming Dahlias in cultivation. Try a half dozen of these. Price

10 cents

BRIDE. Show. Beautiful light lavender, edged heliotrope. Petals exquisitely quilled. Flowers very round and good. Clear, distinct outline. Price

CUBAN GIANT. Show. Dark reddish maroon. Flowers of great size, measuring 6 inches across; stands erect on very long stems well above the foliage. The immense number of large richly hued flowers presents a magnificent appearance. Price

25 cents

DREER'S WHITE. Clear snow-white flower of fine form and gigantis size. Price

DREER'S YELLOW. Clear yellow of fine form and immense. Price 50 cents

ELIZABETH LINSLEY, H. S. Wonderful free flowering, long stems, well above foliage, A No. 1 cut flower and exhibition seedling, 1918. Price.... 50 cents

EMILY. A very attractive, large free blooming Dahlia of fine form. Color, a delicate lavender, overlaid with white. Long, stiff stems. Price

GEN. MILES. Most immense and massive lavender pink striped purplish magenta, unique color, one of the best. Price

GRAND DUCHESS MARIE. (Show.) Seedling introduced 1911. Blooms in profusion. Stems from 12 to 18 inches in length; color is very striking, rich buff overlaid orange; reverse petals pink. Good garden variety. Price

25 cents

MAD. H. FURTADO. (Show.) Large, pure white, good stem and free garden or exhibition Dahlia. Price

20 cents

MAUD ADAMS. A per'ect snowball with a faint lavender blush on the t:ps of the petals, the plants are a pcrfect bank of flowers resembling a huge bouquet. One of the most desirable for cut flowers. Price......... 35 cents

SALMON QUEEN. One of the best show Dahlias grown. No worms, lice or bugs eat or have anything to do with this Dahlia. Price.......... 25 cents 
VIVIAN. A great favorite which received the admriation of every one who saw its wonderful flowers, the color being white effectively edged rose-violet. An extremely wonderful blending of color possessed only by the rare novelties. One of our champions of this season's introductions and a variety worthy of the highest words of praise. Price.

W. W. RAWSON. Show. This popular novelty has been the admiration of all wherever shown the past season. The massive, perfect flowers, often measuring 6 inches across, are born on stiff stems about 15 inches long. The entire flower is absolutely perfect in outline and formation. The color is pure white, overlaid with amethyst blue. Price

25 cents

\section{Collarette}

The grace and beauty of the Collarette Dahlia places it in the forefront of all garden flowers. The colors range from brilliant contrasts to the softest combinations of tints, and the quantity of bloom produced in a season is wonderful. We have selected the following with due regard to form as well as other characteristics and they will prove to be a most useful set.

JOHN BULL. A huge collarette on a giant stem. Color, clear velvety crimson with yellow disc and white collar. Price

85 cents

MAURICE RIVOIRE. The best of the entire collection. A massive flower of a dark crimson with a heavy pure white collar. $2 \frac{1}{2} \mathrm{ft}$. Price ........ 15 cents

MIZAR. (Stredwick) Also a fancy Collarette, but with a pink to white ground, thickly striped scarlet. Flowers medium size, neat and exceedingly pretty. The plants bushy and free. This is certainly in many respects our best Collarette. Height 4 -ft. Price 50 cents

SOUVENIR DE CHABANNE. Ground color lemon yellow, with coralred markings; collar petals very abundant and long. lemon yellow, tipped white. Price 35. cents 


\section{轩ompon 西ablias}

BELLE OF SPRINGFIELD. Very pretty shade of light red. The smallest Dahlia known. Very round and regularly formed, blossoms of diminutive size. Price

10 cents

NERISSA. (New.) The advance in this miniature type of Dahlias has not kept pace with the other classes, and it is but rarely that we have a novelty to offer, but in Nerissa we have su:h a perfect little gem that it should be included in every collection. The plant is of ideal habit and always loaded with flowers of perfect form and of that beautiful shade of lively mauve that appeals to every one and that shows up so fine under artificial light. $4 \mathrm{ft}$. Price

50 cents

SUNBEAM. Vermilion flame. Tubers. Price

15 cents

SNOWCLAD (P. P.) Pure white. Price

15 cents

\section{Single 两ablia}

DORIS. A No. 1 single, large purple flowers, stems $2 \mathrm{ft}$, very free. $6 \mathrm{ft} .4$. Price

25 cents

HELEN. The best single to date, extra long stems, extra free flowers 5 to 8 inches, red shaded white to conter. Price 20 cents

VIRGINIA. Extra good pink and white, long stems, good keeper, tall growing plant. An exhibition flower of high merit 50 cents 


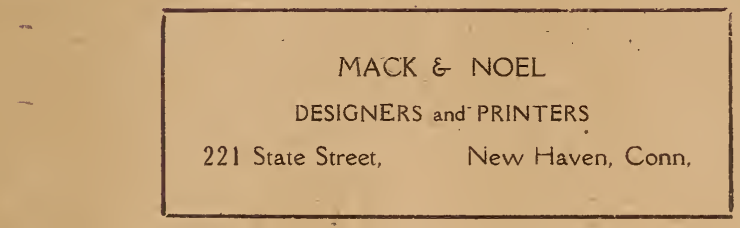

221 State Street, New Haven, Conn, 
